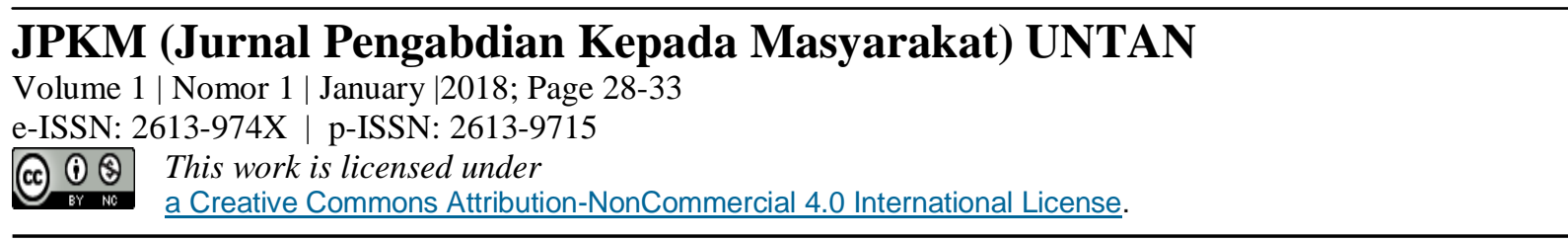

\title{
Dissemination: Education Teacher Based on Gatra Eka Dharma Catur
}

\author{
Marzuki $^{1}$, Sri Utami ${ }^{2}$, Suhardi Marli ${ }^{3}$ \\ Universitas Tanjungpura, Pontianak, Indonesia \\ Email: utamisri 108@gmail.com
}

\author{
Keywords : \\ Catur Gatra Eka Dharma, \\ Pancasila, TeacherHymne, \\ Teacher Competence and \\ Professionalism
}

\begin{abstract}
The problem of learning in primary schools is still prevalent in Melawi Regency is the image of teaching teachers who are still not integrated and cultivate the values contained in Catur Gatra (Pancasila, Teacher Hymn, Teacher Competence and Professionalism). Basically, this gatra catur is a unity of noble devotion. To practice and practice it requires a change of mindset - the teacher changes the paradigm of traditional teaching patterns to the mindset and act of educating contemporaries called change "teaching to learning". The purpose of this dissemination is to ground and practice catur gatra eka dharma teachers in Melawi. The method used is lecture, question and answer and simulation. Participants of the principals' dissemination activities, elementary school teachers, MI as many as 427 people, consisting of 225 women and 2002 men. The result of the questionnaire of dissemination activities distributed by the Committee Chairman is (1) the participants are very enthusiastic about the elimination of Catur Gatra (proven overflow of participants/teachers who previously prepared only 300 seats turned out to increase to 427) (2) teachers feel new insights about Chatur Gatra Eka Dharma as a form of noble devotion; (3) Through the descriptions of Catur Gatra it is expected that teachers can develop character education in Primary School / Madrasah Ibtida'iyah.
\end{abstract}

\section{INTRODUCTION}

Facing globalization or "contemporary era" filled with challenges, competition, and uncertainty of time and direction required visionary teachers and able to manage the learning process in the classroom effectively, efficiently and innovatively. To cope with the change of learning service, it is necessary to change the strategy and the learning model which gives the students a fun nuance.

In the past and present, the atmosphere of the learning environment is often perceived as a torturous or error-seeking, boring, less stimulating, and monotonous environment where learners are forced and less enthusiastic. On the other hand, the teachers are also in an unpleasant environment and are often caught in daily routines. Hence the need to change the "mindset" - the teacher changes 
the paradigm (mindset) of the teacher, from the traditional mindset to the professional mindset commonly called "teaching to learning". Especially with the birth of Law Teachers and Lecturers, Number 14 of 2005 and Government Regulation No. 19 of 2005 which requires a teacher who is qualified, competent and certified. Kindergarten, elementary, junior and senior high school teachers are at least as qualified as Bachelor (S1), have and are able to implement pedagogic, personality, social and professional competence, and have teacher certificate as educator.

Teachers are positions and professional workers. The indicator for measuring professionalism is that if the teacher has the ability to make his / her classroom become a "paradise for learners", or the presence of a classroom teacher is always awaited by the students. Teachers serve as learning resources, facilitators, managers, mentors, motivators, inspirators, demonstrators, evaluators. Teachers become role models both attitude/action, speech and acts of patience, honest, interesting and sincere (Marzuki, 2009: 7). If this role is well executed and the right effort to provide optimal learning services towards the approach of Quantum Teaching or PAIKEM based "Catur Gatra Eka Dharma" God willing will be achieved well.

\section{METHOD}

Catur Gatra-Eka Dharma dissemination activities were conducted with lectures, simulations, and frequently asked questions. Dissemination activities can run smoothly, exciting, fun teachers of SD / MI in Melawi District CGED dissemination participants. At the end of the CGED dissemination activities were distributed questionnaires about responses and the importance of understanding CGED. The teacher gained insight into the Chatur Gatra Eka Dharma as a form of noble devotion. Through the descriptions of Catur Gatra teachers are ready to practice and develop character education in Primary School / Madrasah Ibtida'iyah.

\section{RESULTS AND DISCUSSIONS}

\section{A. The Essence of the Gatra-Eka Dharma Catur as a Noble Covenant}

Schools such as primary schools as one of the basic educational institutions have a very fundamental function in preparing qualified human resources. SD is the basic/foundation of the educational process that exists in the next level. The problem that arises at the moment is how teachers of elementary, junior and senior high schools can improve the quality of learning to achieve quality output education.

Allow me this opportunity to present an idea in contact with the professionalism of the teacher, namely "Chatur Gatra Eka Dharma Luhur". The concept of Catur Gatra Eka Dharma Tunggal is a unique city planning concept. Gatra Tunggal Catur is a concept that many of us meet in various cities, especially cities that have the kingdom or former kingdoms in ancient Java. This concept is sometimes referred to as the civic center which means the part of the city that is spatially central to the various activities of its inhabitants (Kunarto, 2007: 80).

Catur Gatra Eka Dharma Guru is meant as follows: Catur of Sanskrit means four (4), while gatra means element. Literally, gamma catur is the four elements of Pancasila, Hymne teacher, Teacher code of ethics and Profession of teachers who become intact concentration as requirement of noble agreement form (Marzuki, 2015: 4). Pancasila as the central/main gatra, the teacher Hymne is the expression "unattended hero, teacher code of ethics as" gatra form of teaching act character "and teacher profession is fulfilled competence that must exist in teacher. Catur = four, Gatra = element or element, and Eka $=$ one and Dharma $=$ Devotion, Luhur $=$ a noble deed. So Catur GatraEka Dharma is the four elements that are made into one unity to realize the noble dedication as the noble agreement of the teachers in educating.

From the above description of Catur Gatra which is intended in this paper are a. Pancasila (as central gatra); b. Teacher code of ethics (gatra's form); c. Hymn teacher; and D. Teacher profession. The four elements are integrated into a unified whole that becomes a noble agreement in realizing the image and performance of professional teachers. Let us understand and amalkan with based on sincerity and wholehearted, honest and communication partnership. 


\section{B. Elements of "CATUR GATRA EKA DHARMA" as a Sublime Treaty.}

1) Pancasila

Historically, Pancasila was formulated with the aim of being used as the basis of the State of Indonesia Merdeka which in its formulation was extracted and derived from the values of the worldview of society (Syamsudin, 2011: 1). Pancasila is a set of ideas and central gatra and noble agreement of the Indonesian nation that is universal. Pancasila as the basis of the State, and the ideology of the state is a political agreement when the State was established, and until now the globalization era, the State of Indonesia still cling to Pancasila as the foundation of the State of Indonesia. In the Era of globalization, Pancasila role is certainly very important to maintain the Indonesian personality existence nation.

Gatra in the first precepts (Belief in the One Supreme), contained the meaning: 1) Teacher must exemplify himself in worship and honor who has religion and belief in God Almighty to others different from himself; 2) Teachers never impose their religious beliefs and beliefs on others; 3) Teachers must have habluminallah, that is to have confidence in God Almighty, to worship and to pray according to religion and belief; and 4) Must have a clear heart, honest, loving, compassionate, calm, clean or a basis of sincerity towards the relationship with God. How father and mother as teachers in modeling themselves to their students.

Gatra's second principle: Just and civilized humanity, gives guidance: 1) The teacher must look upon his neighbor as his equal rights and obligations; 2) Be considerate; 3) No arbitrary against others/learners, and 4) Dare to defend justice and truth. How father and mother as teacher can exemplify themselves to their students from the aspect of humanism/humanity in school. Are the teachers and teachers accustomed to applying the pattern of college/school life with the principle of humanizing humans?

Gatra's third principle: Unity of Indonesia, provides guidance: 1) The teacher places unity, unity, interests, salvation above personal / group interests; 2) Love the homeland and nation, willing to sacrifice for the homeland and nation; 3) Feel proud as Indonesia and Indonesia's land. Remember compulsory songs or struggle songs, such as Indonesia Raya, Tanah Airku, Satu Nusa Satu Bangsa, Garuda Pancasila, Teguh sturdy Steel Layered, Keluan Coconut Island, Garuda in my chest, and so forth. Similarly, we must remember with four Pillars of Nationality: Pancasila, 1945 Constitution, NKRI and Bhineka Tunggal Ika.

Gatra's fourth principle: Democracy led by the wisdom in representatives deliberations. With this every teacher: 1) Prioritizing the interests of the State and society; 2) Prioritize deliberation in making decisions for the common good; 3) Not impose the will on others; 4) Deliberation for consensus with the spirit of kinship, with both the responsibility of accepting and implementing the results of the deliberation decisions; 5) Deliberation with common sense and in accordance with a noble conscience to make decisions and be accountable to God Almighty; and 6) uphold the dignity of human beings and the values of truth and justice.

Gatra's fifth principle: Social justice for all Indonesian people, in this principle the teacher must: 1) Develop noble deeds and reflect the attitude of kinship and mutual cooperation; 2) Be fair, and maintain a balance between rights and obligations; 3 ) Respect the rights of others; 4) Not living wasteful, not excessively luxurious life, 5) Likes to work hard, 6) Respect the work of others; and 7) Together embodying equitable progress and social justice.

From the above description can be concluded that the Sila-sila in Pancasila is the noble values that are upheld nationally by the nation of Indonesia. Thus, Pancasila is not only the foundation of the Republic of Indonesia but also the Life View of the Indonesian Nation. That is the meaning, function and the essential role of Pancasila for the nation of Indonesia. The other meanings, such as soul, personality, philosophy of the nation and others, basically have been built together in two terms of function and the role mentioned above. By actually applying the pattern of foster-nurture and exertion framed by the leadership of "Tut Wuri Handayani" and with the foundation on Pancasila as the central gatra sincerely and belonging to him, the teacher's image and teacher's performance will continue to climb in the proper place.

2) Master Hymne

Song Hymne Guru as an idol for the teacher is not exaggerated to say so, although the teacher who said. This second Gatra includes: 
"Praise be to You, Mother-Teacher. Your name will always live in my soul, all your devotion will be engraved in my heart. As an inscription of my thanks for your devotion. You are a lamp in the darkness. You are like the dew of conditioning in thirst. You are the patriot of the nation's heroes of a scholar".

The Hymne content of this teacher actually contains "The noble value" for the award on "Teacher Services". But a teacher is also charged as a person of personality and virtuous. With this teacher Hymne, the teachers themselves should be able to bring and position themselves as human beings/teachers who: 1) Praised, can be role models (exemplary); 2) devote himself with "3A (Teach-Asih) and Tut Wuri Handayani" are sincere; 3) Become a lamp in the dark (Lighters, Intelligence, Educators); 4) Being a conditioning dew in thirst; 5) Become the patriot of the nation's hero in realizing the "Nation Character Building", 6) Being the implementer and supporter of 4 pillars of nationality (Pancasila, 1945 Constitution, NKRI, Bhineka Tunggal Ika). If so Hymne Teachers combined with Pancasila need to be socialized or earthed to the teachers or educators and simultaneously to shape the character of learners in the future.

3) Ethic CodeGuru as Gatra form.

This code of ethics of teachers is based on the code of ethics of Indonesian teachers, which can be justified because it is produced by the Congress of Indonesian Teachers Association (PGRI). This material reflects a set of values about which teachers should be, how teachers should behave and behave. By applying the code of ethics as a gatra form in the learning process in class $3 \mathrm{~A}$ and Tut Wuri Handayani, fun, meaningful will improve the image of the teacher to be better, quality in the future.

This teacher's Code of Conduct contains some of the values that pertain to:

a) Teach teachers to educate and guide learners to be Pancasila development human beings. According to Djama'an Satori (2008: 5.9) states that it means that teachers must always carry out their educational tasks based on Pancasila values, for example: to educate noble virtuous children by not violating the dignity of children, to teach honesty, to instill the values of Nationalism, fostering the spirit of unity and unity and so on.

b) The teacher is able to implement the curriculum according to the needs of the child (learners).

c) Teachers master and have a profession that is actually "Master", both in the task of education, learning, coaching students and schools.

d) The teacher knows who and how the learners are.

e) Teachers able to build relationships, cooperation between teachers with teachers in harmony, teachers with parents learners in the true sense (understand and understand the community).

f) Teachers are able to build relationships with surrounding communities, including understanding the environment and cooperation well and regularly.

Generally it can be specified that the function of teachers code of ethics functions: (1) so that teachers have clear guidance and direction in carrying out their duties, so avoid the professional deviation; (2) for teachers to be responsible for their profession; (3) that the teaching profession should be spared from internal divisions and interests; (4) in order for teachers to improve the quality and quantity of services, so that the professional service of teachers is recognized and used by the community; (5) that this profession helps in solving problems and developing oneself; and (6) that the teaching profession should be protected from interference by other professions and the government. Implementation of the code of ethics of teachers in the implementation of their duties, related to the understanding and responsibility for the role and task of teachers, especially in organizing the learning system. even if you want to get a place of hearted learners then teachers are deemed necessary to hold the code of ethics as an educator.

Code of ethics of Indonesian teachers in the performance of their duties, including:

a) The devoted teacher guides the learners to form a Pancasila-spirited Indonesian man.

b) The teacher owns and carries out professional honesty.

c) The teacher seeks to obtain information about the learner as a material for guidance and coaching.

d) Teacher creates the school atmosphere as well as possible to support the success of the learning process.

e) Teachers maintain good relationships with parents and surrounding communities to foster 
participation and a sense of responsibility towards education.

f) The teacher personally and jointly develops and improves the quality and dignity of his profession.

g) Teachers maintain peer professional relationships, family spirit, and social solidarity.

h) Teachers jointly maintain and improve the quality of the organization as a means of struggle.

i) The teacher carries out all government policies in the field of education.

From the above description can be concluded teachers are state officials in the field of education from the State based on Pancasila. Teachers are the best labor of educational development efforts from generation to generation (the educated) who will become the nation's successor in the hands of teachers. In this code of ethics, Indonesian teachers will mean Hymne teacher "Hero Insan Cendikia" this will be realized.

4) Teacher Professionalism

The teacher is a profession, which means a position that requires special skills as a teacher and can not be done by anyone outside the field of education (Hamzah, 2007: 15). Profession becomes the fourth gatra in realizing together the central gatra (Pancasila), Gatra Hymne teacher, Gatra form (Code of ethics of teachers). The development of the teacher profession has actually been well developed through Teacher Based Education Ability (PGBK). A teacher's professional is a necessity in realizing a knowledge-based school, which is an understanding of learning, curriculum, and human development including learning styles (Kariman in Hamzah, 2007: 18). As an educator should master the 4 competencies in learning, namely: professional competence, personality competence, pedagogic competence and social competence.

Professional competence includes: 1) Mastering materials (study materials); 2) Mastering the deepening of field of study; 3) Mastering the methodology of field of study, 4) Mastering the way of assessing the field of study; 5) Mastering the proper management of instructional teaching programs can: (a) formulate instructional objectives; (b) using varied teaching methods, (c) selecting appropriate instructional procedures, (d) being able to implement a teaching and learning program; (e) know the learners well; (f) plan and implement remedial learning; and 6) manage the class well ;; 7) Creating a good teaching and learning climate; 8) using good media/learning resources; and 9) Mastering educational foundations: (a) Philosophical (Pancasila / Philosophy of Education) and (b) schools as reforming institutions); and 10) Manage the class with good learning-teaching interaction.

Personality competence, based on human nature as an individual being and as a creature of God. He is required to master the knowledge that will be taught to the learners properly and responsibly, to have a supporting knowledge about the physiological, psychological conditions and to understand the development of learners and the ability to treat them individually.

Pedagogical competence, the ability to master the science of didactic-method, namely the science of educating, educational style, models, strategies, methods and learning techniques. This competence becomes a marker/feature that is not owned by other professions that are written in the code of ethics teacher.

Social competence, as social beings and ethical beings. He should be able to treat learners fairly and aim to achieve the optimization of potential in each learner. A teacher must understand and apply the principles of humanistic learning. who assume that the success of learning is determined by the abilities that exist in the learners themselves. The teacher's social competence is related to the ability to communicate with learners and their environments, such as parents, neighbors, and friends. (Hamzah, 2007: 19).

With the preparation, practice, and acquisition of such good experience, in mastering the competence of the teacher can be regarded as a professional teacher. In a learning process, two important elements are teaching methods and learning methods. Both are related. The selection of one particular teaching method will influence the appropriate type of instructional media, although there are still other aspects that must be considered in choosing the media, including learning objectives, the type of tasks and respond expected learners mastered after the learning takes place and the learning context including the characteristics of participants educate.

Nevertheless, it can be said that one of the functions of Chatur Gatra Eka-Dharma is as a foothold which certainly participates affect the learning climate, learner process, condition and learning environment arranged and created by educator (teacher). In fact in the field of social studies subjects are still using conventional teaching methods that impact on the effectiveness of learning in 
the classroom. For that required a fun learning process. All materials and improvements in teaching and learning process are done with Chatur Gatra-Eka Dharma so as to streamline the learning process.

\section{CONCLUSION}

Due to the present globalization of the nation and the State of Indonesia cannot avoid the challenge of globalization. By making Catur Gatra Eka Dharma as the guidance and noble agreement in facing globalization Indonesia will still be able to maintain the existence and identity of the Indonesian nation, love of Pancasila and Indonesian homeland (NKRI).

My advice to the teachers and the readers is expected to maintain the nation's personality in facing the challenges of globalization, and can take positive things from the effects of globalisation by sticking to Pancasila as the basis of the State so as to assist the development and development of the State in realizing the revolution mental and quality education.

\section{REFERENCES}

Diana Nomida Musnir. 2015. Paper: Presented in National Seminar on Education "Present and Future Based Mental Revolutionary Education" at PGSD FKIP UNTAN Pontianak, February 26, 2015.

Djam'an Satori. 2008. Teacher Profession. Jakarta: Universitas Terbuka.

Forrest W. Parkay and Beverly Hardcastle Stanford, 2008. Becoming a Teacher. Boston: Pearson Education, Inc.

Gene E. Hall, Linda F Quinn; and Donna M Gollnick, 2008. The Joy of Teaching, Making a Difference in Student Learning. Las Vegas: University of Nevada, Pearson Education, Inc.

Hamzah. 2007. Profession of Education. Jakarta: Earth Literacy.

Kunarto, 2007. Tri Brata and Catur Prasetya History-Perspectives and Prospects. Jakarta: Cipta Manunggal.

Marzuki. 2015. Paper: Presented in the National Seminar on Education "Development of Teacher Professionalism through Catur Gatra in the era of the ASEAN Economic Community (MEA)" at UNY Kampus Wates Kulon Progo, May 2, 2015.

Marzuki and Sri Utami, 2015. Teacher Performance Improvement Of Image And Human Resources Through Quality Four Elements -One Working And Pattern Of Sharpering -Loving - Costading In The School. University of Tanjungpura, West of Kalimantan, Indonesia.

Robert a Reiser and John V. Dempsey, 2007. Trends and Issues in Instructional Design and Technology. New Jersey: Person Merril Prentice Hall.

Sagala, Syaiful. 2011. Professional Ability of Teachers and Education Personnel. Bandung: Alphabeta. Setiyoko, 2015. Planting And Application Of Pancasila Values In Primary School Students In Order To Establish Child Character. Yogyakarta State University.

Syamsudin. 2011. Pancasila Education. Yogyakarta: Total Media.

Usman, Moh. Uzer. 2010. Become a Professional Teacher. Bandung: Remaja Rosdakarya. 